\title{
COLOUR DOPPLER IMAGING IN GIANT CELL (TEMPORAL) ARTERITIS: SERIAL EXAMINATION AND COMPARISON WITH NON-ARTERITIC ANTERIOR ISCHAEMIC OPTIC NEUROPATHY
}

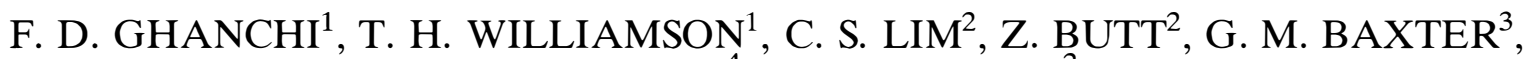 \\ G. McKILLOP ${ }^{4}$ and C. O'BRIEN ${ }^{2}$ \\ Glasgow and Edinburgh
}

\begin{abstract}
SUMMARY
The ophthalmological manifestations of giant cell arteritis (GCA) present a difficult diagnostic and management problem to the ophthalmologist. The orbital circulation is frequently involved in the disease process. The effects of GCA on orbital blood flow assessed by colour Doppler imaging (CDI) were investigated in this study. Serial CDI examinations of the orbital blood vessels were performed (at presentation, 2 days, 1 week and at 1 month) on 7 patients with GCA. CDI examination at presentation was also performed on 4 patients with non-arteritic anterior ischaemic optic neuropathy (AION) for comparison. Blood flow could not be detected in up to three arteries in the affected (ipsilateral) orbit of 6 GCA patients at presentation. Five of these patients were also found to have undetectable blood flow in the posterior ciliary arteries of the contralateral orbit. Serial CDI examination revealed blood flow alterations in arteritic patients despite treatment. Return of blood flow to normal was slow, and related to the clinical features. By contrast, only 1 of the patients with non-arteritic AION showed undetectable blood flow in a posterior ciliary artery. GCA leads to widespread and prolonged alterations in orbital blood flow. CDI allows the detection and monitoring of such alterations in orbital blood flow, which correlate with the clinical features of GCA. Serial CDI examinations in GCA may be used to aid management decisions.
\end{abstract}

Giant cell (temporal) arteritis (GCA) is a systemic

From: ${ }^{1}$ Tennent Institute of Ophthalmology, Western Infirmary, Glasgow; ${ }^{2}$ Princess Alexandra Eye Pavilion, Royal Infirmary of Edinburgh, Edinburgh; ${ }^{3}$ Department of Radiology, Western Infirmary, Glasgow; ${ }^{4}$ Department of Radiology, Royal Infirmary of Edinburgh, Edinburgh, UK.

Correspondence to: Faruque D. Ghanchi, Tennent Institute of Ophthalmology, Western Infirmary, Church Street, Glasgow G11 6NT, UK. vasculitis which can present with severe visual loss. The commonest ophthalmological manifestation of the disease is anterior ischaemic optic neuropathy $(\mathrm{AION}),{ }^{1}$ which is a major cause of acute visual failure. Arteritic AION has a poorer visual prognosis than the non-arteritic type. The latter has been associated with small disc size, ${ }^{2}$ is usually unilateral and tends not to recur, whereas arteritic AION affects any disc size, can be bilateral and is known to recur if the systemic disease process is not well controlled. An accurate diagnosis of GCA is required for both treatment and prognostic reasons, but this may be difficult as there is no pathognomonic sign and conventional investigations such as the erythrocyte sedimentation rate (ESR) may be equivocal., Fluorescein angiography may aid the diagnosis; however, delayed dye appearance and patchy filling of choroid is seen both in arteritic $\operatorname{cases}^{5-7}$ and in non-arteritic AION. ${ }^{8}$ Pulsatile ocular blood flow measurement can support the diagnosis, ${ }^{9}$ but can jeopardise the already compromised circulation. ${ }^{10} \mathrm{~A}$ safe and accurate new investigative modality is required to diagnose and monitor the disease process.

Colour Doppler imaging (CDI) is a proven noninvasive method for determining the blood flow velocities in the orbital vessels ${ }^{11,12}$ and has been employed in the investigation of vascular diseases in this region, including ischaemic optic neuropathy. ${ }^{13-17}$ We have previously described the use of CDI in the management of a patient with GCA, ${ }^{13}$ and recently a CDI study of a series of patients with GCA has been reported. ${ }^{18}$

This paper describes the findings of serial CDI examination based on a pilot study of 7 patients with GCA compared with 4 patients with non-arteritic AION. 


\section{PATIENTS AND METHODS}

Of 11 patients studied with CDI, 7 had GCA and 4 had non-arteritic AION. Clinical data were recorded in all patients, including ESR and histology of temporal artery biopsy. In the arteritic group there were 6 women and 1 man, with a mean age of 81 years (range $76-86$ years). All presented with sudden loss of vision. Six patients had unilateral AION (4 left, 2 right). One patient had bilateral involvement at presentation, the right eye with central retinal artery occlusion (CRAO) and the left eye with probable posterior ischaemic optic neuropathy (PION). GCA was suspected in all 7 patients on the basis of the clinical features (Table I) and later confirmed by positive temporal artery biopsy in 6 cases. Histological findings were inconclusive in 1 patient, but the clinical features were indicative of GCA. All these patients were treated with high-dose systemic steroid ( $80 \mathrm{mg}$ prednisolone orally), pending the result of temporal artery biopsy. In addition, 3 cases with profound visual loss initially received $1 \mathrm{~g}$ methylprednisolone intravenously.

In the non-arteritic group there were 3 men and 1 woman, with a mean age of 63 years (range 56-71 years). All presented with sudden visual loss. Only 1 patient had bilateral involvement. There were no systemic features of GCA in any of these patients.

All the patients were examined in the supine position. Both orbits were examined with a $7.5 \mathrm{MHz}$ probe (Acuson 128, Mountain View, CA) after application of coupling gel. A Doppler gate size of $1.5 \mathrm{~mm}$ was used to sample different vessels. The optimum plane of scan was the transverse plane, and angulation for posterior ciliary arteries was less than $10^{\circ}$. Velocimetric recordings were obtained after angle correction from: (1) the ophthalmic artery; (2) the central retinal artery; and (3) the posterior ciliary arteries running longitudinally, nasal and temporal to the optic nerve in the orbit (for the purpose of this study they are described as the nasal and temporal posterior ciliary arteries, respectively). The latter

Table I. Clinical features recorded in GCA patients A-G

\begin{tabular}{|c|c|}
\hline Clinical feature & Cases \\
\hline Headache & $\mathrm{B}, \mathrm{F}$ \\
\hline Scalp tenderness & $\mathrm{C}$ \\
\hline Malaise & $\mathrm{A}, \mathrm{C}, \mathrm{E}, \mathrm{F}, \mathrm{G}$ \\
\hline Jaw claudication & $\mathrm{A}, \mathrm{B}, \mathrm{C}, \mathrm{D}, \mathrm{E}$ \\
\hline Anorexia & $\mathrm{E}$ \\
\hline Polymyalgia rheumatica & A, G \\
\hline Myalgia & $\mathrm{C}, \mathrm{D}, \mathrm{E}$ \\
\hline Cramps & B \\
\hline Abnormal temporal artery & A, B \\
\hline Raised $\mathrm{ESR}^{\mathrm{a}}$ & $\begin{array}{l}\text { A (87), B (102), D (76), E (90), } \\
\text { F (90), G (74) }\end{array}$ \\
\hline Positive biopsy ${ }^{\mathrm{b}}$ & $\mathrm{A}, \mathrm{B}, \mathrm{C}, \mathrm{D}, \mathrm{E}, \mathrm{F}$ \\
\hline Transient loss of vision & A, B, G \\
\hline Iritis & $\mathrm{C}$ \\
\hline Cilioretinal artery occlusion & G \\
\hline
\end{tabular}

probably represent blood flow velocities of a group of tiny posterior ciliary arteries, evident as a single blood flow map on CDI.

Readings of peak systolic velocity (PSV) and enddiastolic velocity (EDV) were taken and Resistive Index $(\mathrm{RI})$ was calculated as follows: $\mathrm{RI}=(\mathrm{PSV}-$ EDV)/PSV. The velocity measurements were averaged from three pulse waveforms to minimise errors induced by physiological variation.

All the patients had an initial CDI examination within 24 hours of presentation. The patients with GCA had further examinations at 2 days, 1 week and 1 month.

\section{RESULTS}

Qualitative blood flow alterations in the orbital blood vessels were seen in all arteritic cases, the commonest feature being undetectable blood flow. This was observed in 6 patients, all of whom had undetectable blood flow in two to four arteries in the affected orbit. In the contralateral orbit there was absent flow in the posterior ciliary arteries in 5 of the 7 patients at presentation. The normal range of blood flow velocities of orbital vasculature has been previously described by us. ${ }^{19}$ The findings of CDI examination of patients with GCA at presentation and serial follow-up are presented in Tables II, III and IV. The detailed results of CDI examination for patients with non-arteritic AION are given in Table V.

The patients with GCA are described below with their respective CDI findings.

\section{Patients with Stable Visual Status}

Three patients' visual acuity remained stable at the level of presentation with steroid treatment. Two of the 3 patients $(\mathrm{B}, \mathrm{E})$ showed undetectable blood flow (Fig. 1a) in one or both posterior ciliary arteries of the affected orbit at initial examination (Table II).

Table II. Serial CDI examination results of GCA patients with stable vision

\begin{tabular}{|c|c|c|c|c|c|}
\hline \multirow[b]{2}{*}{ Patient } & \multirow[b]{2}{*}{ Artery } & \multicolumn{2}{|c|}{ Affected eye } & \multicolumn{2}{|c|}{ Unaffected eye } \\
\hline & & $\begin{array}{l}24 \text { hours } \\
\text { PSV/EDV }\end{array}$ & $\begin{array}{c}1 \text { month } \\
\text { PSV/EDV }\end{array}$ & $\begin{array}{l}24 \text { hours } \\
\text { PSV/EDV }\end{array}$ & $\begin{array}{l}1 \text { month } \\
\text { PSV/EDV }\end{array}$ \\
\hline B & $\begin{array}{l}\text { OA } \\
\text { CRA } \\
\text { PCN } \\
\text { PCT }\end{array}$ & $\begin{array}{c}147 / 17 \\
\mathrm{NF} \\
\mathrm{NF} \\
14 / 3\end{array}$ & $\begin{array}{c}144 / 24 \\
12 / 3 \\
7 / 2 \\
10 / 2\end{array}$ & $\begin{array}{c}63 / 5 \\
14 / 1 \\
\mathrm{NF} \\
12 / 2\end{array}$ & $\begin{array}{l}70 / 8 \\
15 / 4 \\
13 / 4 \\
14 / 4\end{array}$ \\
\hline $\mathrm{D}$ & $\begin{array}{l}\text { OA } \\
\text { CRA } \\
\text { PCN } \\
\text { PCT }\end{array}$ & $\begin{array}{r}34 / 5 \\
13 / 2 \\
7 / 2 \\
5 / 2\end{array}$ & $\begin{array}{r}27 / 5 \\
5 / 2 \\
15 / 4 \\
11 / 3\end{array}$ & $\begin{array}{r}13 / 3 \\
7 / 1 \\
7 / 2 \\
8 / 3\end{array}$ & $\begin{array}{r}24 / 4 \\
6 / 2 \\
12 / 4 \\
12 / 3\end{array}$ \\
\hline $\mathrm{E}$ & $\begin{array}{l}\text { OA } \\
\text { CRA } \\
\text { PCN } \\
\text { PCT }\end{array}$ & $\begin{array}{c}98 / 22 \\
8 / 0 \\
\mathrm{NF} \\
\mathrm{NF}\end{array}$ & $\begin{array}{c}70 / 8 \\
7 / 0 \\
\mathrm{NF} \\
\mathrm{NF}\end{array}$ & $\begin{array}{l}29 / 5 \\
15 / 0 \\
\mathrm{NF} \\
\mathrm{NF}\end{array}$ & $\begin{array}{c}48 / 6 \\
16 / 2 \\
\mathrm{NF} \\
\mathrm{NF}\end{array}$ \\
\hline
\end{tabular}

Values are the PSV/EDV (peak systolic velocity/end-diastolic velocity) in $\mathrm{cm} / \mathrm{s}$. NF, no flow detected.

OA, ophthalmic artery; CRA, central retinal artery; PCN, nasal posterior ciliary artery; PCT, temporal posterior ciliary artery. 


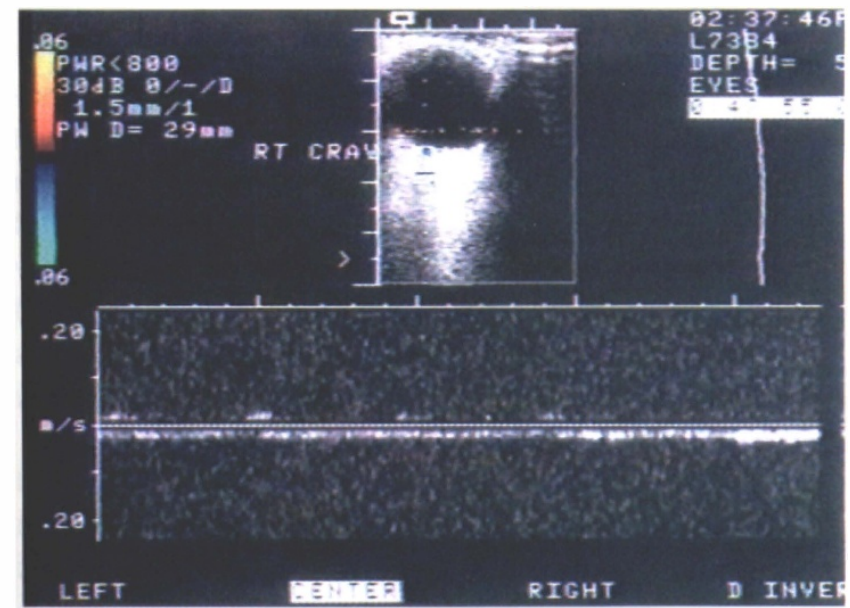

(a)

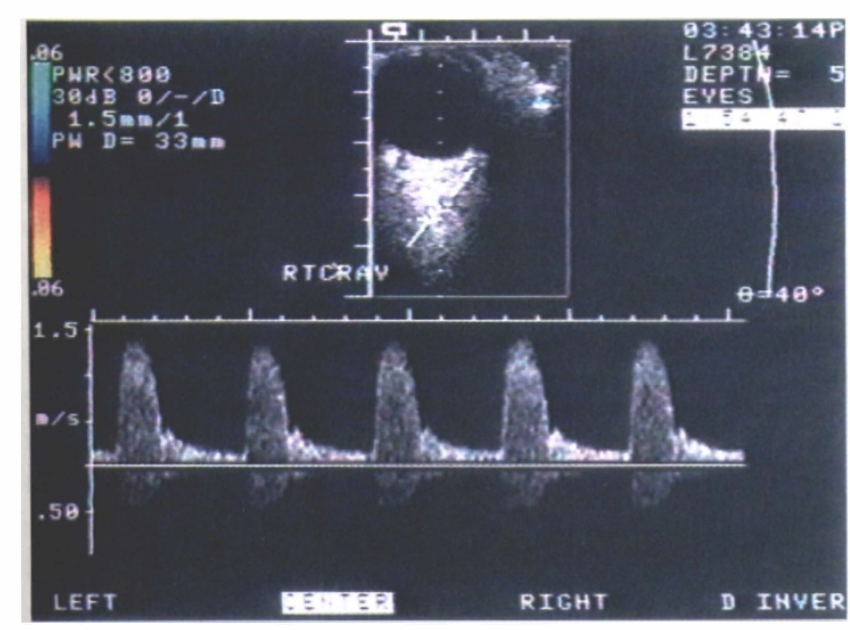

(b)

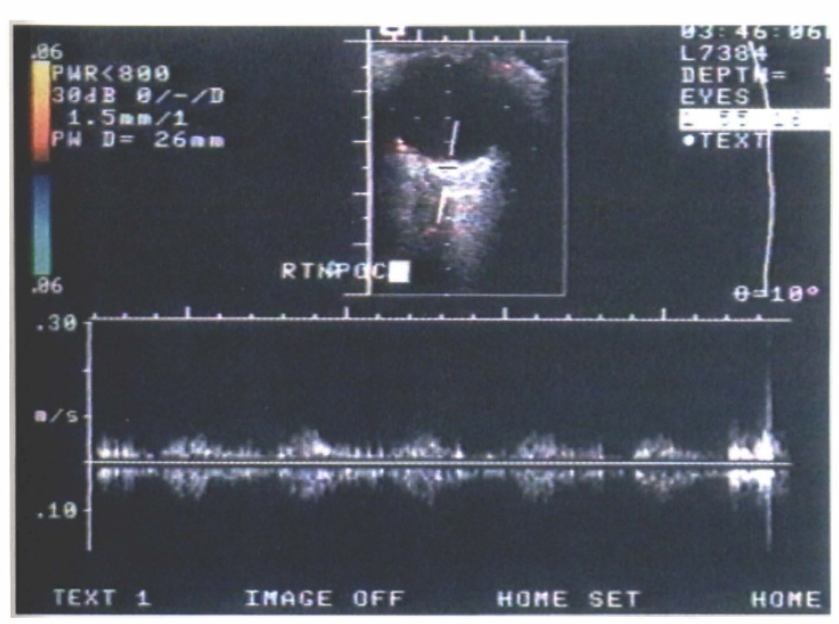

(c)

Fig. 1. Colour Doppler images of the affected orbit of patient B. (a) At presentation there is no detectable blood flow in the central retinal artery. (The nasal posterior ciliary artery in the affected orbit was also undetectable.) (b) Improved blood flow in the central retinal artery at 1 month. (c) Improved blood flow in the nasal posterior ciliary artery at 1 month.
The remaining patient (D) was also found to have undetectable blood flow in the posterior ciliary artery of the affected orbit at 2 days. Blood flow was also undetectable in the central retinal artery of the affected orbit in 1 patient (B) (Table II). These patients showed improvement in the orbital circulation at 1 month (Fig. 1b, c) on follow-up CDI examination (Table II).

Patient with Visual Deterioration in the Affected Eye One patient (C) presented with AION in an ischaemic eye with minimal iritis and low intraocular pressure. The patient's vision in the affected eye deteriorated from 6/60 to no perception of light after 2 days despite treatment with high doses of prednisolone. CDI examination at presentation recorded undetectable blood flow in the posterior ciliary arteries of the affected eye (Table III). Two days later, no measurable blood flow in the ipsilateral orbit could be detected with CDI (a Doppler result of 'empty socket'). This remained unchanged at 1 week, but at 1 month complete reversal of flow in the ophthalmic artery was detected, which was not associated with to and fro blood flow. The central retinal artery was found to have improved blood flow but the posterior ciliary arteries remained undetectable. Interestingly, the contralateral orbit (clinically unaffected eye) showed a high ophthalmic artery peak systolic velocity $(192 \mathrm{~cm} / \mathrm{s})$ associated with normal velocities proximal and distal to this area, suggesting an ophthalmic artery stenosis (Fig. 2). These features remained unchanged on subsequent examinations with CDI (Table III). Clinically the contralateral eye remained unaffected.

Patients with Deterioration of Vision in the Contralateral Eye

Two patients (A and $G$ ) were found to have worsening of visual acuity in the fellow eye after

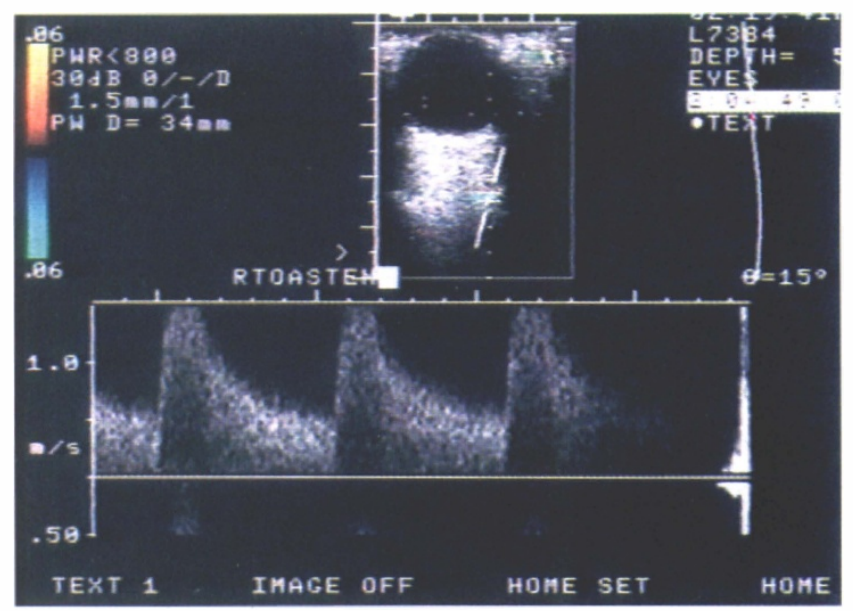

Fig. 2. A colour Doppler image of the ophthalmic artery of patient $C$ on the unaffected side, demonstrating very high blood flow velocities. 
Table III. Serial CDI examination results of GCA patients with deterioration in vision

\begin{tabular}{|c|c|c|c|c|c|}
\hline \multirow[b]{2}{*}{ Patient } & \multirow[b]{2}{*}{ Artery } & \multicolumn{2}{|c|}{ Affected eye } & \multicolumn{2}{|c|}{ Unaffected eye } \\
\hline & & $\begin{array}{l}24 \text { hours } \\
\text { PSV/EDV }\end{array}$ & $\begin{array}{l}1 \text { month } \\
\text { PSV/EDV }\end{array}$ & $\begin{array}{l}24 \text { hours } \\
\text { PSV/EDV }\end{array}$ & $\begin{array}{l}1 \text { month } \\
\text { PSV/EDV }\end{array}$ \\
\hline$A$ & $\begin{array}{l}\text { OA } \\
\text { CRA } \\
\text { PCN } \\
\text { PCT }\end{array}$ & $\begin{array}{c}\text { NF } \\
\text { NF } \\
65 / 27 \\
\text { NF }\end{array}$ & $\begin{array}{l}\mathrm{NE} \\
\mathrm{NE} \\
\mathrm{NE} \\
\mathrm{NE}\end{array}$ & $\begin{array}{c}56 / 14 \\
7 / 1 \\
N F \\
6 / 2\end{array}$ & $\begin{array}{c}18 / 8 \mathrm{~W} \\
5 / 2 \\
8 / 2 \\
9 / 4\end{array}$ \\
\hline $\mathrm{C}$ & $\begin{array}{l}\text { OA } \\
\text { CRA } \\
\text { PCN } \\
\text { PCT }\end{array}$ & $\begin{array}{l}22 / 13 \\
5 / 2 \\
\text { NF } \\
\text { NF }\end{array}$ & $\begin{array}{l}9 / 4^{\mathrm{r}} \mathrm{W} \\
3 / 1 \\
\mathrm{NF} \\
\mathrm{NF}\end{array}$ & $\begin{array}{c}59 / 23- \\
192 / 85 \\
14 / 3 \\
9 / 4 \\
18 / 6\end{array}$ & $\begin{array}{c}41 / 13- \\
\text { OR/OR } \\
8 / 2 \\
9 / 2 \\
12 / 3\end{array}$ \\
\hline G & $\begin{array}{l}\text { OA } \\
\text { CRA } \\
\text { PCN } \\
\text { PCT }\end{array}$ & $\begin{array}{r}26 / 6 \\
\text { NF } \\
\text { NF } \\
\text { NF }\end{array}$ & $\begin{array}{l}22 / 4 \\
\mathrm{NF} \\
\mathrm{NF} \\
\mathrm{NF}\end{array}$ & $\begin{array}{r}29 / 5 \\
14 / 3 \\
\mathrm{NF} \\
\mathrm{NF}\end{array}$ & $\begin{array}{l}10 / 2 \mathrm{~W} \\
10 / 2 \\
\mathrm{NF} \\
\mathrm{NF}\end{array}$ \\
\hline
\end{tabular}

Values are the PSV/EDV in $\mathrm{cm} / \mathrm{s}$. NF, no flow detected; NE, eye not examined at patient's request; OR, out of range, very high velocity; $r$, reversed blood flow.

Abbreviations for arteries as in Table II. W, worsened.

presentation. At presentation, CDI examination of the affected eyes showed widespread involvement of the orbital vessels (Table III). In both patients, the fellow eyes also showed undetectable blood flow in the posterior ciliary arteries at presentation (Table III). The follow-up CDI examination also showed poor circulation in both orbits (Table III).

\section{Patient with Bilateral Involvement at Presentation}

One patient (F) had bilateral involvement at presentation, a central retinal artery occlusion in the right eye and probable posterior ischaemic optic neuropathy in the left. Initial CDI examination showed no detectable flow in the central retinal artery and both the posterior ciliary arteries in the right orbit. The left orbit also showed no detectable flow in the posterior ciliary arteries (Table IV). The patient's vision deteriorated to light perception in both eyes despite treatment. Repeat CDI examination at 1 month showed no detectable flow in the posterior ciliary arteries in the right orbit, while the central retinal artery showed flow with high resistance. The blood flow remained undetectable in the posterior ciliary arteries of the left eye (Table IV).
Table IV. Serial CDI examination results of a patient with GCA and bilateral involvement

\begin{tabular}{|c|c|c|c|c|c|}
\hline \multirow[b]{2}{*}{ Patient } & \multirow[b]{2}{*}{ Artery } & \multicolumn{2}{|c|}{ Right eye } & \multicolumn{2}{|c|}{ Left eye } \\
\hline & & $\begin{array}{l}24 \text { hours } \\
\text { PSV/EDV }\end{array}$ & $\begin{array}{l}1 \text { month } \\
\text { PSV/EDV }\end{array}$ & $\begin{array}{l}24 \text { hours } \\
\text { PSV/EDV }\end{array}$ & $\begin{array}{l}1 \text { month } \\
\text { PSV/EDV }\end{array}$ \\
\hline \multirow[t]{4}{*}{ A } & $\mathrm{OA}$ & $27 / 5$ & N/A & $21 / 4$ & NA \\
\hline & CRA & NF & $5 / 0$ & $12 / 3$ & $8 / 2$ \\
\hline & PCN & NF & NF & $\mathrm{NF}$ & $\mathrm{NF}$ \\
\hline & PCT & $\mathrm{NF}$ & NF & NF & $\mathrm{NF}$ \\
\hline
\end{tabular}

Values are PSV/EDV in $\mathrm{cm} / \mathrm{s}$. NF, no flow detected; NA, data not available due to technical error.

Abbreviations for arteries as in Table II.

\section{Patients with Non-arteritic AION}

The 4 patients with non-arteritic AION also presented with sudden loss of vision. Three of these $(\mathrm{H}$, I and $\mathrm{K}$ ) showed no anomaly on CDI examination. One patient $(\mathrm{J})$ was found to have undetectable blood flow in one posterior ciliary artery of the affected orbit at presentation (Table V). However, the blood flow was found to be normal in this vessel at 2 days and has remained normal since.

\section{DISCUSSION}

The inflammatory process of GCA commonly affects the ophthalmic artery, the posterior ciliary arteries and the central retinal artery. ${ }^{19}$ In this study, all GCA patients showed altered blood flow in the orbital vessels on CDI examination. The most consistent finding in this group was the absence of detectable blood flow in the posterior ciliary arteries, evident in 6 of 7 cases. Although blood flow velocity results from the posterior ciliary arteries with CDI have poor reproducibility, their detection is usually possible in normal individuals. ${ }^{20}$ Absent colour Doppler indices in the patients described probably indicate absent or very low blood flow in these vessels. Absent posterior ciliary blood flow has been reported by previous investigators ${ }^{13,14.18}$ and is compatible with the clinico-pathological findings of frequent involvement of the posterior ciliary circulation in the arteritic process. ${ }^{19}$ In addition, 4 of our patients with GCA had undetectable flow also in the ipsilateral central retinal artery, perhaps indicating occlusion at the emergence of these vessels from the ophthalmic artery. Indeed, Hayreh ${ }^{21,22}$ has described a common origin of the central retinal artery and

Table v. CDI findings in non-arteritic AION

\begin{tabular}{|c|c|c|c|c|c|c|c|c|}
\hline \multirow[b]{2}{*}{ Patient } & \multicolumn{4}{|c|}{ Affected eye } & \multicolumn{4}{|c|}{ Unaffected eye } \\
\hline & $\begin{array}{c}\text { OA } \\
\text { PSV/EDV }\end{array}$ & $\begin{array}{c}\text { CRA } \\
\text { PSV/EDV }\end{array}$ & $\begin{array}{c}\text { PCN } \\
\text { PSV/EDV }\end{array}$ & $\begin{array}{c}\text { PCT } \\
\text { PSV/EDV }\end{array}$ & $\begin{array}{c}\text { OA } \\
\text { PSV/EDV }\end{array}$ & $\begin{array}{c}\text { CRA } \\
\text { PSV/EDV }\end{array}$ & $\begin{array}{c}\text { PCN } \\
\text { PSV/EDV }\end{array}$ & $\begin{array}{c}\mathrm{PCT} \\
\mathrm{PSV} / \mathrm{EDV}\end{array}$ \\
\hline$\overline{\mathrm{H}}$ & $27 / 5$ & $12 / 3$ & $10 / 3$ & $22 / 7$ & $32 / 5$ & $15 / 3$ & $8 / 3$ & $15 / 5$ \\
\hline I & $40 / 11$ & $10 / 3$ & $11 / 3$ & $13 / 4$ & $84 / 17$ & $17 / 4$ & $11 / 3$ & $17 / 4$ \\
\hline $\mathbf{J}$ & $27 / 10$ & $7 / 2$ & $8 / 1$ & NF & $99 / 13$ & $9 / 3$ & $10 / 3$ & $16 / 5$ \\
\hline $\mathrm{K}$ & $29 / 10$ & $6 / 3$ & $5 / 1$ & $5 / 3$ & $46 / 16$ & $10 / 4$ & $9 / 3$ & $4 / 3$ \\
\hline
\end{tabular}

Patient I had bilateral AION at presentation. Patient J, with undetectable flow in a posterior ciliary artery, was subsequently found to have normal velocities in the affected artery at 1 week.

Values are PSV/EDV in $\mathrm{cm} / \mathrm{s}$. NF, no detectable blood flow.

Abbreviations for arteries as in Table II. 
posterior ciliary artery from the ophthalmic artery in some individuals. One patient showed absent flow in the ophthalmic artery and resultant 'empty socket' on CDI, perhaps indicating a proximal occlusion of this vessel. Retrograde flow was observed in this vessel at 1 month follow-up CDI examination. These findings suggest an occlusion of the ophthalmic artery with subsequent re-perfusion from the external carotid circulation.

In 5 patients, alterations in blood flow were seen in the arteries of the contralateral orbit, most commonly with absence of detectable flow in the posterior ciliary arteries. This finding may indicate a subclinical arteritic process, affecting the vasculature of the fellow orbit. Alterations of blood flow in the posterior ciliary arteries of the unaffected orbit have been reported in a recent study. ${ }^{18}$ One of our patients had contralateral ophthalmic artery blood flow velocities consistent with a focal stenosis along its course in the orbit. The eye was asymptomatic, presumably due to the lesion being distal to the site of exit of the central retinal artery and posterior ciliary arteries.

The histological changes of GCA in the vessel wall can be detected up to a week after commencement of steroid treatment. ${ }^{23}$ It may be that the inflammation in the vessel wall and related changes in its lumen take longer to resolve, and may alter the vessel structure permanently. Indeed, 4 of the 7 patients had persistent abnormalities of blood flow 1 month after presentation. In addition, 2 of our patients even showed a reduction in the blood flow at 2 and 7 days before returning to haemodynamic patterns similar to that at presentation.

In 4 of the 7 patients with GCA the vision deteriorated despite administration of high-dose steroids. In 1 patient the visual acuity in the affected eye deteriorated during the course of treatment. CDI examination at the time recorded markedly reduced blood flow velocities leading to an 'empty socket'. In 2 patients vision deteriorated in the 'unaffected' fellow eyes. Both these patients had undetectable blood flow in the posterior ciliary arteries of the fellow orbit prior to worsening of vision. The patient with bilateral involvement was found to have severe, widespread reduction in blood flow involving posterior ciliary arteries in both orbits and the central retinal artery in the right orbit.

It would appear that the deterioration in vision despite treatment is associated with a reduction in the number of vessels with measurable blood flow (patients $\mathrm{A}$ and $\mathrm{C}$ ), or with reduced ophthalmic artery blood flow velocities (patients $\mathrm{A}, \mathrm{C}$ and $\mathrm{G}$ ). Therefore, CDI examination during the course of therapy may help to ascertain the risk of further deterioration. Examination of a larger cohort of patients is required to determine whether $\mathrm{CDI}$ is predictive of visual outcome in GCA.

The precise aetiology of non-arteritic AION remains unexplained but the ischaemic insult in this condition may be due to temporary alterations in the perfusion pressure in the posterior ciliary arteries. ${ }^{5,6.24}$ In contrast to the patients with GCA, only 1 of the 4 non-arteritic AION patients was found to have temporarily undetectable blood flow in one posterior ciliary artery. The findings in this study of unaltered blood flow in most of the patients with non-arteritic AION may reflect the temporary disturbance of blood flow. The absence of detectable blood flow in the posterior ciliary arteries in patients with AION may be useful in differentiating nonarteritic from arteritic cases.

In conclusion, CDI provides a useful means of assessing patients with GCA. Though the findings are not uniform, the generalised and persistent alterations in blood flow can be deemed characteristic of the arteritic disease. As observed in this study, absence of detectable flow in the posterior ciliary arteries, altered central retinal artery flow together with the anomalous posterior ciliary artery haemodynamics, very high ophthalmic artery blood flow velocity, reversal of blood flow in the ophthalmic artery and haemodynamically 'empty socket' could support a diagnosis of GCA. In addition, a reduction in the number of arteries with detectable blood flow and reduction in the flow velocity in the ophthalmic artery on CDI is associated with a poorer visual prognosis. CDI appears to be a useful means of assessing the severity of ophthalmic arteritic disease and also in the temporal monitoring the disease process.

We thank Mrs E. McLaughlin of Medical Illustrations, Southern General Hospital, Glasgow, for assistance with photographs.

Key words: Anterior ischaemic optic neuropathy, Blood flow, Colour Doppler imaging, Giant cell (temporal) arteritis.

\section{REFERENCES}

1. Cullen JF, Coleiro JA. Ophthalmic complications of giant cell arteritis. Surv Ophthalmol 1976;20:247-60.

2. Jonas JB, Guesk GC, Naumann GO. Anterior ischemic optic neuropathy: nonarteritic form in small and arteritic in normal sized optic discs. Int Ophthalmol 1988;12:119-25.

3. Cullen JF. Occult temporal arteritis. Trans Ophthalmol Soc UK 1963;83:725-36.

4. Jacobson DM, Slamovits TL. Erythrocyte sedimentation rate and its relationship to hematocrit in giant cell arteritis. Arch Ophthalmol 1987;105:965-7.

5. Hayreh SS: Anterior ischaemic optic neuropathy: fundus on ophthalmoscopy and fluorescein angiography. Br J Ophthalmol 1974;58:964-80.

6. Hayreh SS. Anterior ischaemic optic neuropathy: differentiation of arteritic from nonarteritic type and its management. Eye 1990;4:25-41.

7. Siatkowski RM, Gass JD, Glaser JS, Smith JL, Schatz 
NJ, Schiffman J. Fluorescein angiography in the diagnosis of giant cell arteritis. Am J Ophthalmol 1993;115:57-63.

8. Arnold AC, Helper RS. Fluorescein angiography in acute nonarteritic anterior ischemic optic neuropathy. Am J Ophthalmol 1994;117:222-30.

9. Bosley TM, Savino PJ, Sergott RC, Eagle RC, Sandy R, Gee W. Ocular pneumoplethysmography can help in the diagnosis of giant-cell arteritis. Arch Ophthalmol 1989;107:379-81.

10. Bates JH. Ocular pneumoplethysmography in giant cell arteritis. Arch Ophthalmol 1989;107:1279.

11. Baxter GM, Williamson TH, McKillop G, Dutton GN. Colour Doppler ultrasound of orbital and optic nerve blood flow: effects of posture and timolol $0.5 \%$. Invest Ophthalmol Vis Sci 1992;33:604-10.

12. Lieb WE, Cohen SM, Merton DA, Shields JA, Mitchell DG, Goldberg BB. Colour Doppler imaging of the eye and orbit: technique and normal vascular anatomy. Arch Ophthalmol 1991;109:527-31.

13. Williamson TH, Baxter G, Paul R, Dutton GN. Colour Doppler ultrasound in the management of a case of cranial arteritis. Br J Ophthalmol 1992;76:690-1.

14. Williamson TH, Baxter GM, Dutton GN. Colour Doppler velocimetry of the optic nerve head in arterial occlusion. Ophthalmology 1993;100:312-7.

15. Erickson SJ, Hendrix LE, Massaro BM, Harris GJ, Lewandowski MF, Foley WD, Lawson TL. Colour Doppler flow imaging of the normal and abnormal orbit. Radiology 1989;173:511-6.

16. Guthoff RF, Berger RW, Winkler P, Helmke K, Chumbley LC. Doppler ultrasonography of the ophthalmic and central retinal vessels. Arch Ophthalmol 1991;109:532-6.

17. Flaharty PM, Sergott RC, Lieb WE, Bosley TM, Savino PJ. Optic nerve sheath decompression may improve blood flow in the anterior ischaemic optic neuropathy. Ophthalmology 1993;100:297-305.

18. Ho AC, Sergott RC, Regillo CD, Savino PJ, Lieb WE, Flaharty PM, Bosley TM. Colour Doppler haemodynamics of giant cell arteritis. Arch Ophthalmol 1994;112:938-45.

19. Wilkinson IM, Russell RW. Arteries of the head and neck in giant cell arteritis: a pathological study to show the pattern of arterial involvement. Arch Neurol 1972;27:378-91.

20. Williamson TH, Lowe GDO, Baxter GM. Influence of age, systemic blood pressure, smoking and blood viscosity on orbital blood velocities. $\mathrm{Br} \mathrm{J}$ Ophthalmol 1995;79:17-22.

21. Hayreh SS. Ophthalmic artery. III. Branches. Br J Ophthalmol 1962;46:212-47.

22. Hayreh SS. Interindividual variation in blood supply of the optic nerve head: its importance in various ischaemic disorders of the optic nerve head, and glaucoma, low tension glaucoma and allied disorders. Doc Ophthalmol 1985;59:217-46.

23. Allison MC, Gallagher PJ. Temporal artery biopsy and corticosteroid treatment. Ann Rheum Dis 1984;43: 416-7.

24. Hayreh SS, Zimmerman MB, Podhajsky P, Alward WLM. Nocturnal arterial hypotension and its role in optic nerve head and ocular ischaemic disorders. Am J Ophthalmol 1994;117:603-24. 